\title{
ANALISIS EFIKASI DIRI DALAM PEMECAHAN MASALAH MATEMATIS PESERTA DIDIK KELAS XI MA DARUL ULUM
}

\author{
Imroatus Sholihah ${ }^{1}$, Zainul Munawwir ${ }^{2}$, dan Irma Noervadila ${ }^{3}$ \\ ${ }_{1,2,3}$ STKIP PGRI Situbondo, Indonesia \\ imroatus9989@gmail.com
}

\begin{abstract}
The purpose of this study is to describe self-efficacy in internal student's mathematical problem solving in terms of students' mathematical ability class XI MA Darul Ulum 2019/2020 school year. This type of research is descriptive qualitative. The subjects of this study were 2 students of class XI MA Darul Ulum with different mathematical ability, namely high and fair. Data collection techniques in this study were observation, interviews, tests problem solving, and documentation. Analysis of the data in this study analyzed on each data collection technique. The results of data analysis show that level of self-efficacy in the problem solving of each students are different, on the student with high mathematical ability show high self-efficacy, student with fair mathematical ability show low self-efficacy, but in problem solving of students with fair mathematical ability are better than the students with high mathematical ability.
\end{abstract}

Keywords: Self-efficacy, Problem solving

\begin{abstract}
Abstrak: Tujuan penelitian ini adalah mendeskripsikan efikasi diri pada peserta didik dalam pemecahan masalah matematis ditinjau dari kemampuan matematika peserta didik kelas XI MA Darul Ulum tahun pelajaran 2019/2020. Jenis penelitian ini adalah deskriptif kualitatif. Subjek penelitian ini adalah dua peserta didik kelas XI MA Darul Ulum dengan kemampuan matematika yang berbeda yaitu tinggi dan sedang. Teknik pengumpulan data dalam penelitian ini adalah observasi, wawancara, tes pemecahan masalah, dan dokumentasi. Analisis data dalam penelitian ini dianalisis pada setiap teknik pengumpulan data. Hasil analisis data menunjukkan bahwa tingkat efikasi diri dalam pemecahan masalah dari masingmasing peserta didik adalah berbeda, pada peserta didik berkemampuan matematika tinggi menunjukkan efikasi diri yang tinggi, peserta didik berkemampuan matematika sedang menunjukkan efikasi diri yang rendah, namun dalam pemecahan masalah peserta didik berkemampuan matematika sedang lebih baik dari pada pemecahan masalah peserta didik berkemampuan matematika tinggi.
\end{abstract}

Kata kunci: Efikasi diri, Pemecahan masalah

\section{PENDAHULUAN}

Matematika merupakan salah satu mata pelajaran yang berperan penting dalam pengembangan ilmu pengetahuan dan teknologi. Setiap peserta didik mempunyai pandangan yang berbeda tentang pelajaran matematika, bagi peserta didik yang menganggap pelajaran matematika menyenangkan, akan tumbuh keyakinan dalam diri peserta didik untuk mempelajari matematika. Sedangkan, bagi 
peserta didik yang menganggap pembelajaran matematika menyeramkan, akan tumbuh rasa malas untuk mempelajari matematika. Salah satu caranya adalah merangsang keaktifan peserta didik dan memotivasi peserta didik dalam pembelajaran matematika (Tefa, Idayani, dan Astindari, 2019). Sehingga peserta didik akan lebih percaya diri dan mempunyai minat dalam pembelajaran matematika.

Berdasarkan pernyataan di atas, maka peneliti tertarik untuk menganalisis efikasi diri. Efikasi diri adalah keyakinan seseorang akan kemampuan dirinya untuk mampu mengatasi dan menyelesaikan suatu permasalahan sehingga menghasilkan hasil yang positif dalam belajar matematika (Minarti dan Nurfauziah, 2016; Subaidi, 2016; Evaliana, 2015; Nurlaila, 2011; Utami dan Wutsqa, 2017; Sandra dan Djalali, 2013; Yusuf, 2011; Akram dan Ghazanfar, 2014; Chotima, Hartono, dan Kesumawati, 2019). Dari pernyataan di atas dapat disimpulkan bahwa efikasi diri merupakan keyakinan akan kemampuan diri sendiri untuk menyelesaikan permasalahan, khususnya dalam menyelesaikan masalah matematika.

Menurut Bandura (dalam Masitoh dan Hartono, 2017), Efikasi diri mencakup tiga dimensi, yaitu; 1) magnitude, berkaitan dengan tingkat kesulitan suatu tugas yang dilakukan, 2) generality (generalisasi) berkaitan dengan bidang tugas, seberapa luas individu mempunyai keyakinan dalam melaksanakan tugastugas, 3) strength (kekuatan/ ketahanan), berkaitan dengan kuat lemahnya keyakinan seorang individu.

Berdasarkan pengamatan dan pengalaman peneliti bahwa tingkat efikasi diri peserta didik mempunyai peran penting dalam beberapa aspek untuk mewujudkan tujuan pembelajaran, salah satunya dalam pemahaman konsep dan pemecahan masalah matematis. Jika peserta didik memiliki pemahaman konsep yang baik, maka pemecahan masalahnya akan menunjukkan hasil yang baik (Surur, Degeng, Setyosari, dan Kuswandi, 2020). Hal tersebut menunjukkan bahwa adanya hubungan khusus antara efikasi diri dengan pemecahan masalah matematis. Artinya, efikasi diri menjadi bagian yang sangat penting dalam pemecahan masalah matematis peserta didik.

Menurut Netriwati (2016) pemecahan masalah adalah keterampilan dasar yang harus dimiliki oleh setiap peserta didik agar mampu mencari solusi dan 
menyelesaikan permasalahan matematika. Dari pernyataan di atas dapat disimpulkan bahwa pemecahan masalah matematis merupakan kemampuan dasar yang harus dimiliki oleh peserta didik untuk menyelesaikan suatu permasalahan matematika. Pemecahan masalah erat kaitannya dengan kemampuan matematika yang dimiliki oleh peserta didik.

Menurut Polya (dalam Hidayat dan Sariningsih, 2018), pemecahan masalah memuat empat langkah penyelesaian yaitu 1) memahami masalah, 2) merencanakan penyelesaian, 3) menyelesaikan masalah sesuai rencana, dan 4) melakukan pengecekan kembali terhadap semua langkah yang dikerjakan. Berdasarkan uraian di atas dan diperkuat dengan fakta yang ada, maka tujuan dalam penelitian ini adalah untuk mendeskripsikan efikasi diri dalam pemecahan masalah matematis peserta didik.

\section{METODE}

Jenis penelitian ini adalah penelitian deskriptif-kualitatif, artinya menggambarkan atau mendeskripsikan kejadian-kejadian yang menjadi pusat perhatian (efikasi diri dalam pemecahan masalah matematis) secara kualitatif dan berdasar pada data kualitatif. Penelitian ini dilaksanakan di MA Darul Ulum yang bertempat di Jl. Cermee No. 12, Kapongan, Situbondo.

Sumber data dalam penelitian ini adalah peserta didik kelas XI MA Darul Ulum tahun pelajaran 2019/2020. Namun hanya dua peserta didik yang menjadi subjek penelitian. Subjek dipilih pada kriteria kemampuan matematika yang tinggi dan sedang. Teknik pengumpulan data yang digunakan dalam penelitian ini adalah triangulasi teknik, yaitu observasi, tes pemecahan masalah matematis, wawancara, dan dokumentasi. Analisis data pada penelitian ini dianalisis pada setiap tekhnik pengumpulan data.

\section{HASIL DAN PEMBAHASAN}

\section{Hasil}


Subjek penelitian dianalis dengan melihat tingkat efikasi diri dalam setiap langkah pemecahan masalah untuk menentukan tingkat efikasi diri pada masingmasing subjek.

Tabel 1. Subjek penelitian

\begin{tabular}{cccc}
\hline $\begin{array}{c}\text { Nilai } \\
\text { Kemampuan } \\
\text { Matematika }\end{array}$ & $\begin{array}{c}\text { Kategori } \\
\text { Kemampuan } \\
\text { Matematika }\end{array}$ & $\begin{array}{c}\text { Nilai } \\
\text { Subjek }\end{array}$ & $\begin{array}{c}\text { Kode } \\
\text { Subjek }\end{array}$ \\
\hline $70 \leq x<85$ & Tinggi & 82 & ST \\
\hline $55 \leq x<70$ & Sedang & 68 & SS \\
\hline
\end{tabular}

Subjek berkemampuan matematika tinggi (ST)

Dalam memahami masalah ST sudah percaya diri dengan menuliskan yang diketahui dalam soal untuk mempermudah penyelesaian, serta dalam menjawab setiap pertanyaan dari peneliti ST menjawab dengan tegas. Dalam merencanakan penyelesaian ST mampu merencanakan dengan baik, hal tersebut ditunjukkan ST mengalikan diketahui dalam soal yang merupakan langkah benar dalam penyelesaian soal terkait, namun dalam melakukan perhitungan ST kurang menyederhanakan soal yang membuat jawaban menjadi salah, akan tetapi ST mempunyai rasa keyakinan yang baik terhadap hasil kerjanya.

\section{Subjek berkemampuan matematika sedang (SS)}

Dalam soal tes pemecahan masalah yang diberikan, SS mampu memahami soal dengan cukup baik, akan tetapi rasa percaya diri ketika menyebutkan informasi dari soal, SS masih ragu untuk menjawabnya. Perencanaan penyelesaian SS sudah baik, ditunjukkan SS mengalikan yang diketahui dalam soal dengan sekawannya dengan benar, tetapi SS masih bertanya kepada peneliti untuk melakukan langkah selanjtnya, hal tersebut menunjukkan bahwa rasa kepercayaan diri SS masih rendah. Dari rasa kurang percaya diri SS membuat perhitungan dalam proses penyelesaian menghasilkan jawaban yang salah, padahal dalam menyelesaikan masalah SS sudah baik.

\section{Pembahasan}


Berdasarkan hasil analisis data yang telah dipaparkan dari hasil tes pemecahan masalah matematis dan hasil wawancara, menujukkan bahwa ST dalam memahami masalah sudah baik. Hal ini dapat dilihat saat ST dengan lancar menuliskan informasi yang didapatnya tanpa ada rasa ragu. Hal tersebut membuktikan bahwa ST sudah percaya diri dalam menuliskan informasi yang didapatnya. Pernyataan tersebut juga diperkuat ketika proses wawancara berlangsung, ST dengan penuh keyakinan menjawab setiap butir pertanyaan yang ditanyakan oleh peneliti tanpa ada rasa takut.

Dalam merencanakan penyelesaian, ST memiliki keyakinan yang tinggi dalam merencanakan penyelesaian dengan baik. Hal ini ditunjukkan ketika ST menuliskan rencana yang diambilnya untuk menyelesaikan permasalahan yang terdapat dalam soal dengan cepat tanpa berfikir lama serta tanpa ada keraguan sedikitpun. ST dengan penuh percaya diri menjawab setiap pertanyaan yang ditanyakan oleh peneliti ketika proses wawancara berlangsung. Hal tersebut dapat membuktikan bahwa tingkat efikasi diri yang dimilki ST dalam merencanakan penyelesaian adalah tinggi.

Dalam melakukan perhitungan, ST kurang teliti dalam melakukan perhitungan. Kesalahan yang dilakukan oleh ST terletak pada operasi hitung yaitu kurang menyederhanakan fungsi aljabar sebelum memasukkan nilai limxnya. Tingkat efikasi diri ST dalam melakukan perhitungan adalah tinggi. Sebab terlalu tinggi rasa percaya diri yang dimiliki ST, menyebabkan ST tanpa sadar melakukan kesalahan saat melakukan perhitungan.

Hal tersebut didukung pada saat proses wawancara berlangsung, ST dengan penuh kepercayaan diri menjawab bahwa yang dikerjakannya sudah benar, padahal ST masih salah dalam menyederhanakan fungsi aljabarnya. Hal itu membuktikan bahwa kepercayaan diri yang dimiliki ST dalam melakukan perhitungan hanya percaya kepada dirinya saja tanpa didasari oleh penguasaan materi yang dimilikinya.

Pada tahap terakhir pemecahan masalah, tingkat efikasi diri ST dalam mengecek kembali penyelesaian adalah tinggi. Hal tersebut dapat terlihat ketika proses wawancara berlangsung. ST dengan penuh percaya diri menjawab bahwa 
hasil kerjanya sudah benar dan sudah melakukan mengecekan kembali setiap langkah yang dikerjakannya.

Namun ST belum memahami dengan baik setiap langkah yang dikerjakannya sehingga membuat hasil yang diperolehnya masih salah. Dari rasa kepercayaan diri ST yang tinggi, membuat diri ST terlalu yakin bahwa pekerjaannya sudah benar dan kurang mengevaluasi kembali jawaban dari langkah yang dikerjakannya.

Dari pernyataan diatas, dapat disimpulkan bahwa efikasi diri yag dimiliki ST dalam memahami masalah, merencanakan masalah, melakukan perhitungan, dan mengecek kembali penyelesaian adalah tinggi. Pernyataan tersebut diperkuat oleh pernyataan Thaha dan Rustan (2017) dan Masitoh dan Fitriyani (2018) bahwa seseorang dengan efikasi diri yang tinggi akan percaya bahwa mereka mampu melakukan sesuatu untuk menyelesaikan suatu permasalahan matematika sehingga dapat mendukung keberhasilan proses pembelajaran matematika dan dapat meningkatkan prestasi siswa. Namun ST kurang teliti dalam melakukan operasi hitung. Hal tersebut dikarenakan ST memilki rasa kepercayaan dan keyakinan yang terlalu tinggi terhadap kemampuannya tanpa diimbangi dengan penguasaan materi yang dimilki ST dalam menyelesaikan permasalahan.

Pernyataan tersebut didukung oleh informasi yang didapat dari guru matematika bahwa ST memang memiliki tingkat efikasi diri yang tinggi dalam pembelajaran, serta dari hasil proses pengamatan saat mengerjakan, ST dengan penuh rasa percaya diri mengerjakan dengan fokus dan lancar tanpa keraguan. Ketika proses wawancara berlangsung ST menjawab dengan tegas dan yakin setiap poin yang ditanyakan oleh peneliti.

Berbeda dengan ST, tingkat efikasi diri yang dimilki SS dalam memahami masalah adalah rendah. Hal tersebut dapat dilihat ketika SS masih kurang percaya diri dalam menuliskan informasi yang ditemukannya dalam soal sehingga SS masih bertanya terlebih dahulu kepada peneliti untuk langkah pertama yang ingin dikerjakannya. Karena kurang percaya diri yang dimiliki SS membuat dirinya merasa tidak mampu menyelesaikan permasalahan dalam soal.

Dalam merencanakan penyelesaian, SS sudah mampu merumuskan langkah penyelesaian, namun masih kurang yakin dengan langkah yang diambil untuk 
menyelesaikan permasalahan yang terdapat dalam soal. Hal tersebut membuktikan bahwa tingkat efikasi diri yang dimiliki subjek SS dalam merencanakan penyelesaian adalah rendah.

Hal itu dapat terlihat ketika SS merencanakan penyelesaian masih kurang yakin dengan langkah yang diambilnya. Sebenarnya SS sudah baik dalam merumuskan, tapi karena rasa kurang percaya dirinya membuat SS masih bertanya kebenaran langkah yang diambilnya dalam merumuskan penyelesaian dalam soal tersebut.

Saat melakukan perhitungan, SS masih banyak mengeluh karena kurang percaya dengan kemampuannya dalam melakukan perhitungan. Sehingga menimbulkan rasa ingin menyerah disaat tengah mengerjakan soal. Hal tersebut membuktikan bahwa tingkat efikasi diri yang dimiliki SS dalam melakukan perhitungan adalah rendah. Karena rasa kurang percaya diri SS sehingga membuat SS melakukan kesalahan dalam operasi hitung penjumlahan dan perkalian aljabarnya. Kesalahan yang dilakukan oleh SS lebih baik dari kesalahan yang dilakukan ST. SS hanya kurang teliti dan fokus dalam melakukan penjumlahan dan perkalian aljabarnya. Hal tersebut dikarenakan saat proses pengerjaan, SS terlalu banyak mengeluh dan ingin menyerah dalam menyelesaikan soal.

Pada tahap mengecek kembali penyelesaian yang sudah dikerjakan, SS masih ragu dengan jawaban yang sudah dikerjakannya. Hal tersebut menunjukkan bahwa tingkat efikasi diri yang dimiliki SS dalam mengecek kembali penyelesaian adalah rendah. Kemampuan SS dalam menyimpulkan hasil dari penyelesaian masih kurang. Oleh sebab itu, SS tidak yakin dengan jawabannya sendiri.

Dari rasa keraguan dan ketidak percayaan yang dimiliki SS membuat dirinya tertekan sehingga menyebabkan hasil yang didapat kurang benar. Hal itu dikarenakan SS masih kurang fokus dan yakin dalam mengecek kembali jawaban dari setiap langkah yang dikerjakannya. Hal lain yang membuat SS tidak percaya diri adalah pengusaaan materi dalam tes pemecahan masalah yang kurang dengan beberapa sebab yang ada, salah satunya terlalu lamanya SS tidak mengulang pelajaran yang sudah dipelajari pada kondisi saat ini.

Dari pernyataan diatas, dapat disimpulkan bahwa efikasi diri yang dimiliki SS dalam memahami masalah, merencanakan masalah, melakukan perhitungan, 
dan mengecek kembali penyelesaian adalah rendah. Karena rasa tidak percaya diri yang dimiliki SS sehingga menyebabkan hasil yang kurang benar dalam menyelesaikan proses penyelesaiannya. Hal tersebut juga didukung oleh pernyataan Wahyuni (2013) dan Chan dan Abdullah (2018) bahwa seseorang dengan efikasi diri rendah menganggap dirinya pada dasarnya tidak mampu mengerjakan persoalan matematika dan cenderung menghindari tugas tertentu karena adanya keraguan dalam dirinya untuk mampu menyelesaikan persoalan yang dihadapi.

Pernyataan tersebut juga dibuktikan dari informasi yang didapat dari guru matematika bahwa SS kurang percaya diri dan belum yakin dengan kemampuannya sehingga masih melihat hasil pekerjaan temannya. Saat proses wawancara berlangsung, cara SS menjawab setiap pertanyaan yang ditanyakan oleh peneliti masih kurang percaya diri sehingga merasa takut untuk menyampaikan pendapatnya dengan leluasa.

\section{SIMPULAN}

\section{Kesimpulan}

Berdasarkan hasil dan pembahasan, dapat disimpulkan bahwa peserta didik berkemampuan matematika tinggi memiliki tingkat efikasi diri yang tinggi akan tetapi masih kurang teliti dalam proses pemecahan masalahnya. Hal tersebut menunjukkan bahwa tingkat efikasi diri yang tinggi tidak selalu menghasilkan hasil yang positif. Peserta didik berkemampuan matematika sedang memiliki tingkat efikasi diri yang rendah. Pada proses pemecahan masalahnya, peserta didik juga masih kurang teliti dalam melakukan perhitungan.

\section{Saran}

Berdasarkan pengalaman penelitian di lapangan mengenai efikasi diri, efikasi diri sangat menarik untuk dikaji lebih lanjut, karena efikasi diri sangat penting dalam proses pembelajaran, sehingga diharapkan bagi penelitian berikutnya efikasi diri dapat dipertimbangkan kembali untuk diteliti bersama variabel lainnya seperti kemampuan komunikasi matematis, serta peneliti berikutnya dapat memilih subjek dari semua kategori kemampuan matematika, yaitu sangat tinggi, tinggi, sedang, rendah, dan sangat rendah sehingga penelitian dapat dilakukan dengan optimal. Peneliti berikutnya juga harus lebih mempersiapkan diri dalam proses 
pengambilan dan pengumpulan data agar penelitian dapat dilaksanakan dengan baik.

\section{DAFTAR RUJUKAN}

Akram, B., \& Ghazanfar, L. (2014). Self Efficacy And Academic Performance Of The Students Of Gujrat University, Pakistan. Academic Research International, 5(1), 283-290.

Chan, H. Z., \& Abdullah, M. N. L. Y. (2018). Validity And Reliability Of The Mathematics Self-Efficacy Questionnaire (MSEQ) On Primary School Students. Pertanika Journal of Social Sciences and Humanities, 26(4), 21612177.

Chotima, M. C., Hartono, Y., \& Kesumawati, N. (2019). Pengaruh Reciprocal Teaching Terhadap Kemampuan Pemecahan Masalah Matematis Ditinjau $\begin{array}{llll}\text { Dari } & \text { Self-Efficacy } & \text { Siswa. } & \text { 14(1), }\end{array}$ https://doi.org/10.21831/pg.v14i1.22375

Evaliana, Y. (2015). Pengaruh Efikasi Diri Dan Lingkungan Keluarga Terhadap Minat Berwirausaha Siswa. Jurnal Pendidikan Bisnis Dan Manajemen, 1(1), $1-70$.

Hidayat, W., \& sari ningsih, R. (2018). Kemampuan Pemecahan Masalah Matematis Dan Adversity Quotient Siswa Smp Melalui Pembelajaran Open Ended. Jurnal JNPM (Jurnal Nasional Pendidikan Matematika), 2(1), 109. https://doi.org/10.1016/S0962-8479(96)90008-8

Masitoh, L. F., \& Fitriyani, H. (2018). Improving Students' Mathematics SelfEfficacy Through Problem Based Learning. Malikussaleh Journal Of $\begin{array}{llll}\text { Mathematics } \quad \text { Learning } & \text { (MJML), }\end{array}$ https://doi.org/10.29103/mjml.v1i1.679

Masitoh, L. F., \& Hartono, H. (2017). Pengembangan Perangkat Pembelajaran Matematika dengan Pendekatan PBL Berorientasi pada Kemampuan Berpikir Kreatif dan Self-Efficacy Developing Mathematics Instructional Materials Using PBL Approach Oriented to Creative Thinking Ability and Self-Efficacy. Jurnal Pendidikan Matematika, 12(2), 220-230.

Minarti, E. D., \& Nurfauziah, P. (2016). Pendekatan Konsturktivisme Dengan Model Pembelajaran Generatif Guna Meningkatkan Kemampuan Komunikasi 
Dan Koneksi Matematis Serta Self Efficacy Mahasiswa Calon Guru Di Kota $\begin{array}{lllll}\text { Cimahi. } & P 2 M & \text { STKIP } & \text { Siliwangi, } & 3(2),\end{array}$ https://doi.org/10.22460/p2m.v3i2p68-83.629

Netriwati. (2016). Analisis Kemampuan Pemecahan Masalah Matematika Berdasarkan Teori Polya Ditinjau Dari Pengetahuan Awal Mahasiswa Iain Raden Intan Lampung. Al-Jabar: Jurnal Pendidikan Matematika, 7(2), 181190.

Nurlaila, S. (2011). Pelatihan Efikasi Diri Untuk Menurunkan Kecemasan Pada Siswa-Siswi Yang Akan Menghadapi Ujian Akhir Nasional. GUIDENA: Jurnal Ilmu Pendidikan, Psikologi, Bimbingan Dan Konseling, 1(1), 1. https://doi.org/10.24127/gdn.v1i1.348

Sandra, K. I., \& Djalali, M. A. (2013). Manajemen Waktu, Efikasi-Diri Dan Prokrastinasi. Persona:Jurnal Psikologi Indonesia, 2(3), 217-222. https://doi.org/10.30996/persona.v2i3.140

Subaidi, A. (2016). Self-Efficacy Siswa Dalam Pemecahan Masalah Matematika. Jurnal Eigma. Universitas Madura, 1(2), 64-68. https://doi.org/10.0324/SIGMA.V1I2.68

Surur, M., Degeng, I. N. S., Setyosari, P., \& Kuswandi, D. (2020). The Effect of Problem-Based Learning Strategies and Cognitive Styles on Junior High School Students' Problem-Solving Abilities. International Journal of Instruction, 13(4).

Tefa, S., Idayani, D., \& Astindari, T. (2019). Perbandingan Hasil Belajar Siswa Antara Pemberian Tugas Kelompok Dan Tugas Individu Pada Mata Pelajaran Matematika Di Smp Negeri 6 Situbondo. EDUSAINTEK: Jurnal Pendidikan Sains Dan Teknologi, 6(1), 23-33.

Thaha, H., \& Rustan, E. (2017). Orientasi Religiusitas dan Efikasi Diri dalam Hubungannya dengan Kebermaknaan Pendidikan Agama Islam pada Mahasiswa IAIN Palopo. Jurnal Studi Agama Dan Masyarakat, 13(2), 163179.

Utami, R. W., \& Wutsqa, D. U. (2017). Analisis Kemampuan Pemecahan Masalah Matematika Dan Self-Efficacy Siswa SMP Negeri Di Kabupaten Ciamis. Jurnal Riset Pendidikan Matematika, 4(2), 166. 
https://doi.org/10.21831/jrpm.v4i2.14897

Wahyuni, S. (2013). Hubungan Efikasi Diri Dan Regulasi Emosi Dengan Motivasi Berprestasi Pada Siswa SMK Negeri 1 Samarinda. EJournal Psikologi, 1(1), 88-95. https://doi.org/10.1107/S0907444994004907

Yusuf, M. (2011). The Impact Of Self-Efficacy, Achievement Motivation, And Self-Regulated Learning Strategies On Students' Academic Achievement. Procedia - Social and Behavioral Sciences, 15, 2623-2626. https://doi.org/10.1016/j.sbspro.2011.04.158 